\title{
A RESSIGNIFICAÇÃO DO CONCEITO DE INIMIGO NA CULTURA PENAL DA IDADE MODERNA
}

\section{THE RESSIGNIFICATION OF THE CONCEPT OF ENEMY IN THE CRIMINAL CULTURE OF THE MODERN AGE}

\author{
José Valente Neto* \\ Jânio Pereira da Cunha*
}

\begin{abstract}
Resumo: O artigo trata da ressignificação do conceito de inimigo na cultura penal da Idade Moderna. Após analisar a origem do conceito na antiguidade clássica, principalmente em Roma, observou-se a sua disciplina na Idade Média e na Idade Moderna. O objetivo consiste, em suma, em investigar a possibilidade de estabelecimento de uma definição de inimigo no âmbito das ordens penais da antiguidade e medievo. O método de pesquisa empregado foi o bibliográfico. Concluiu-se que a política e a pena são temas diretamente relacionados. Neste sentido, é possível identificar a construção de um inimigo no direito penal.
\end{abstract}

Palavras-chave: Inimigo. Cultura penal. Estado moderno. Ressignificação.

Abstract: The article deals with the ressignification of the concept of enemy in the penal culture of the Modern Age. After analyzing the origin of the concept in classical antiquity, especially in Rome, it was observed its discipline in the Middle Age and in the Modern Age.

Keywords: Enemy. Criminal culture. Modern State. Ressignification.

\section{Introdução}

Este trabalho tem como objetivo analisar a ressignificação do conceito de inimigo em um dos períodos mais emblemáticos para a história do direito criminal: Idade Moderna. A relevância do tema reside na escassez de literatura, nacional e estrangeira, e em um vácuo de interpretações por parte dos juristas sobre a transição política e econômica que se operou, sobretudo, na segunda metade do século XVIII e suas repercussões na Europa e na América.

\footnotetext{
* Doutorando em Direito na Universidade Federal do Ceará (UFC). Mestre em Direito Constitucional pela Universidade de Fortaleza (UNIFOR). Defensor Público no Estado do Ceará. Endereço: Rua 8 de Setembro, n. 1130, apto. 2102, Varjota, Fortaleza-CE. CEP: 60.175-210. Email: josevalenteneto1979@gmail.com.

* Professor do Curso de Direito e do Programa de Pós-Graduação em Direito (Mestrado) do Centro Universitário Christus (UNICHRISTUS). Professor do Curso de Direito da Universidade de Fortaleza (UNIFOR). Doutor em Direito Constitucional (UNIFOR). Endereço: Rua 8 de Setembro, n. 1130, apto. 701, Varjota, Fortaleza-CE. CEP: 60.175-210. Email: janiopcunha@hotmail.com
} 
O fato de ser inoportuna uma investigação sob o prisma de um direito internacional de guerra e de um Estado constitucional não inibe uma abordagem sobre as mutações que essa categoria assumiu na trajetória da teoria do poder. Pelo contrário, reforça-a, seja pela perversão, seja pela latência. Almeja-se, precipuamente, responder a três perguntas: i) é possível o estabelecimento de uma definição de inimigo no âmbito das ordens penais da antiguidade e medievo?; ii) porventura afirmativa, quais pessoas eram englobadas neste catálogo?; e iii) quais as consequências das transformações pré-capitalistas na reformulação teórica e na práxis do sistema penal?

Em relação ao primeiro tópico, em face da amplitude superior a um milênio e da sua influência na cultura ocidental, o enfoque se circunscreverá aos hebreus, aos gregos e aos romanos. No tocante ao último quesito, haverá um destaque sobre a gênese do direito natural e o advento de duas instituições caras às formações sociais contemporâneas: a polícia e o sistema penitenciário. $\mathrm{O}$ método de pesquisa empregado foi o bibliográfico e, em face do tratamento propositalmente implícito que a dogmática sempre lhe conferiu, principalmente após a concepção do princípio da igualdade e da legalidade, houve o recurso à ciência política e à filosofia.

\section{A Antiguidade e um conceito de inimigo}

A Antiguidade foi o berço da teocracia. O Japão Imperial e o Egito faraônico, por exemplo, tiveram ordenamentos políticos em cujos substratos o poder era efetivado em nome de uma autoridade divina por homens que se autoproclamaram seus mandatários na Terra. Contudo, o reconhecimento como experiência clássica é atribuído aos hebreus. Com efeito, trata-se de "regime político em que o poder supremo é exercido por uma classe sacerdotal acumulando ao mesmo tempo o poder civil ou temporal e o poder religioso ou espiritual. Ex.: a teocracia dos hebreus" (JAPIASSU; MARCONDES, 2006, p. 265). O “Governo de Deus", honrado por uma casta abençoada e dignificada por uma iluminação celeste, ficou incumbido da salvação eterna e do bem-estar material dos súditos.

O direito hebraico, uma das expressões máximas da hierarquia sacra, foi notabilizado pelo caráter religioso de ações ou omissões que pudessem ser interpretadas como uma violação aos seus preceitos. A transgressão de qualquer lei representava um delito contra o Senhor Deus, onipotente, "Rei dos Céus". O rol de vilipêndios englobava tanto as condutas contra a soberania 
divina quanto contra a autoridade temporal, longa manus do todo-poderoso. Devotos do monoteísmo, os hebreus eram implacáveis com o ultraje à entidade superior, tanto que, em relação às punições, "uma particularidade da lei bíblica era a predominância da pena capital" (SOUZA, 2015, p. 73). Para ofensas mais brandas ao código espiritual eram aplicados os castigos corporais e aos incautos a maldição. Em uma esfera de culpas e promessas de redenção, a desgraça do inferno para pecadores impenitentes significava um ostracismo moral. Conforme a lição de Baruch de Espinosa:

Deus ficou, portanto, com todo o poder sobre o Estado hebreu e só este, graças ao
pacto, podia legitimamente ser chamado o Reino de Deus, da mesma forma que a
Deus se podia chamar com propriedade o Rei dos hebreus. Assim, os inimigos daquele
Estado eram inimigos de Deus, os cidadãos que quisessem usurpá-lo eram réus de
lesa-divina-majestade e, finalmente, as leis em vigor eram as leis e mandamentos
divinos. Nesse Estado, portanto, o direito civil e a religião, que consiste unicamente
em obedecer a Deus, eram uma e a mesma coisa. Quer dizer, os dogmas da religião
não eram ensinamentos mas normas jurídicas e mandamentos, tal como a piedade era
tida por justiça e a impiedade por crime e injustiça. Quem desprezasse a religião
deixava de ser cidadão e só por isso era tido como inimigo; quem tivesse dado a vida
pela religião era como se tivesse morrido pela Pátria; entre o direito civil e a religião
não havia absolutamente nenhuma distinção. Eis o motivo por que a tal Estado pôde
chamar-se "teocracia", porquanto os seus cidadãos não estavam subordinados a
nenhum direito a não ser aquele que Deus tinha revelado. (ESPINOSA, 2008, p. 256-
257). ${ }^{\dagger}$

No helenismo, as cidades-estado não poderiam ser agrupadas em um conjunto homogêneo de valores, crenças e costumes. Apesar de inúmeras interseções, a Grécia Antiga era composta por pólis com peculiaridades inconfundíveis, inclusive religiosas, cujas origens se situam nos povoados independentes espalhados ao longo dos mares Mediterrâneo e Egeu. Tebas e Creta eram importantes entrepostos comerciais. A democracia ateniense diferia da diarquia espartana. Além disso, Atenas foi um dos centros culturais mais desenvolvidos da época, com protagonismo na Arquitetura, na Filosofia e no Teatro*; Esparta se sobressaiu pelo exímio preparo militar dos jovens e até de crianças.

\footnotetext{
† Todavia, em raciocínio subsequente, há uma advertência: "Tudo isso, no entanto, era mais uma suposição do que uma situação de fato, já que os hebreus mantiveram em absoluto o direito estatal. [...]. Num primeiro momento, se aproximaram todos de Deus para ouvir o que lhes queria ordenar; ficaram, porém, tão aterrados nessa primeira prestação de vassalagem e ouviram de tal maneira atônitos a lavra de Deus que julgaram ser chegado o fim dos seus dias. Então, cheios de medo, foram novamente a Moisés: eis que ouvimos Deus falando no meio do fogo e não há razão para que queiramos morrer; esse fogo imenso devorar-nos-á com certeza; se nós ouvirmos outra vez a voz de Deus, por certo morreremos. Vai tu, pois, escuta todas as palavras do nosso Deus e serás tu (não Deus) a falar-nos: tudo o que Deus te disser nós obedeceremos e havemos de cumpri-lo. Com essas palavras, aboliram claramente o primeiro pacto e transferiram por completo para Moisés o seu direito de interpelar Deus e interpretar os seus éditos" (ESPINOSA, 2008, p. 257).

* "O teatro antigo é um complexo fenómeno literário e humano. A sua vida estende-se por um período muito longo, pois a primeira tragédia que sabemos ter sido representada situa-se sob a tirania de Pisístrato, em Atenas, cerca de 534 a. C. E, por outro lado, pode considerar-se que as últimas obras dramáticas por nós conhecidas são as tragédias
} 
Os gregos não possuíram um livro considerado sagrado, tal qual a Bíblia, para os hebreus. Não havia uma divindade em particular, mas uma pluralidade de configurações em torno da soberania, da guerra e da fecundidade. Politeístas, Zeus encarnou, contudo, a força suprema, o deus-rei, representante da justiça. Como advoga Jean-Pierre Vernant, "sem dúvida, um deus grego define-se pelo conjunto de relações que o unem e o opõem às outras divindades do panteão, mas as estruturas teológicas assim evidenciadas são demasiado múltiplas" (VERNANT, 2009, p. 29-30).

Enquanto em outras religiões de matriz indo-europeia o arcabouço figurativo entre mito, ritual e adoração parecem indicar um entrelaçamento mais uniforme e vertical, a (s) religião(ões) grega(s) se comportou de forma mais difusa e horizontal. Os códigos de conduta baseados em uma fé foram as primeiras tentativas do ser humano para responder aos mistérios da vida e da morte, aos enigmas do universo. "Tais crenças, originalmente, davam sentido e ordem a um mundo desconhecido e identificado com o caos, algo sempre temido pelas culturas da Antiguidade, como a Mesopotâmia e a Grécia Clássica" (SILVA; SILVA, 2018, p. 355). ${ }^{\S}$

As Guerras de Troia, Médicas e do Peloponeso confirmam que os conflitos eram relativamente comuns nesta região da Península Balcânica. "Acostumado à guerra e também belicoso: tal era certamente o homem grego" (GARLAN, 2012, p. 66). ${ }^{* *}$ Se o estrangeiro era

de Séneca, escritas, sem dúvida, entre 45 e 60 depois de Cristo. [...] Não devemos esquecer que este teatro se desenvolveu dentro de duas sociedades muito diferentes, na Grécia e, sobretudo, em Atenas, depois em Roma" (GRIMAL, 1986, p. 10).

$\S$ O politeísmo era a regra; o monoteísmo, a exceção: “Atualmente, as duas maiores religiões em números de praticantes são o Islã e o Cristianismo. A terceira, o Hinduísmo, por sua vez, é politeísta. A maioria das civilizações, até o surgimento e a expansão do Cristianismo e do Islamismo, eram politeístas, desde a Grécia clássica passando pelos maias na América Central até as cidades-estado iorubas na África ocidental. A marca de uma religião politeísta é seu panteão diversificado, em que a cada divindade são atribuídas determinadas características" (SILVA; SILVA, 2018, p. 356).

** "Avvezzo alla guerra, e anche bellicoso: tale fu, di certo, l'uomo greco" (GARLAN, 2012, p. 66). A conclusão sobre o espírito beligerante do homem grego deve ser tratada com reticências. Havia um sopesamento e a decisão de guerra era meticulosa, inclusive com menção a tratado e arbitragem. Além disso, a multiplicidade de deuses. É o que revela um trecho de Tucídides: "78. 'Deliberai então ponderadamente, pois estão em jogo matérias nada triviais, e não vos sujeiteis, influenciados pelas opiniões e acusações de outros, a sofrer desnecessariamente com problemas que recairiam sobre vós mesmos. Percebei, antes de ser envolvidos nela, quão grandes são os riscos de erros de estimativa na guerra. Efetivamente, quando se prolonga demais ela tende a depender simplesmente do acaso, e sobre o acaso nenhum dos lados tem poder, pois os resultados entram na esfera do desconhecido e do precário. Muitos se lançam apressadamente à guerra e querem ser os primeiros a agir, embora isto deva ser o último recurso, mas quando se vêem em situação difícil, finalmente resolvem falar. Como, todavia, ainda não estamos envolvidos nesse erro, e vemos que vós ainda não estais, exortamo-vos, enquanto conselhos sensatos são ainda matéria de livre escolha para ambas as partes, a não violar o tratado e não violar os vossos juramentos, e a optar pela solução de nossas divergências mediante arbitragem, de conformidade com o pactuado. Se recusardes, invocaremos como testemunhas os deuses pelos quais juramos, e nos esforçaremos por tomar represálias contra os que começarem a guerra, seguindo o caminho aberto por vós.' 79. Assim falaram os atenienses. Quando os lacedemônios acabaram de ouvir as acusações dos aliados aos atenienses e a resposta destes, mandaram que todos se retirassem e começaram a deliberar, só eles, sobre a situação" (TUCÍDIDES, 2001, p. 45-46). 
muitas vezes o inimigo efetivo, visível, a ser abatido, dominado e escravizado, os grupos que pretendiam a usurpação do poder político eram o inimigo em potencial, sempre dispostos à rebelião. Neste particular, as medidas mais drásticas de repressão e contenção eram destinadas “não só contra o inimigo externo, suas máquinas de cerco e seus estratagemas, mas também contra o inimigo interno, ou seja, os adversários do regime dispostos a trair para ter o melhor" (GARLAN, 2012, p. 76). De acordo com a observação de René Girard, "no Antigo Testamento e nos mitos gregos os irmãos são quase sempre irmãos inimigos" (GIRARD, 1990, 15).

O liame entre religião e direito na experiência penal grega é objeto de celeuma. De um modo geral, "dois mitos têm se perpetuado em nossa cultura, distorcendo os fatos: o de que os gregos não eram fortes em Direito e o da severidade das leis draconianas que tudo puniam com a morte" (SOUSA, 2015, p. 108). ${ }^{\dagger \dagger}$ De modo particular, a discussão sobre a natureza da lei. Arno Dal Ri Júnior argumenta que o crime contra o Estado era, acima de tudo, "um delito de caráter religioso contra a autoridade dos monarcas que se encontravam sob as graças e proteção de entidades divinas" (RI JÚNIOR, 2006, p. 31). Nesta senda, o direito penal assumiu uma feição negativa e consistiu na privação da proteção divina ou na ausência de tutela jurídica ao condenado. Por sua vez, Eugenio Raúl Zaffaroni e José Henrique Pierangeli contestam o parecer e defendem que

em Atenas a pena havia perdido a crueldade que caracteriza as penas antigas. Como consequência da base política da Pólis (cidade-estado grega), sua lei penal não tinha base teocrática: os gregos não julgavam em nome dos deuses. Embora as legislações de Atenas e de Esparta diferenciassem notavelmente, não há dúvidas de que tanto uma como a outra estavam bem distantes da concepção teocrática do Estado. Com Grécia e Roma o direito penal se laiciza, torna-se marcadamente mundano. Essa não será uma conquista definitiva na história do homem porque há um longo caminho de marchas e contramarchas mas, de qualquer maneira, é o momento em que, na antiguidade, alcança-se o maior grau de laicização. O gênio grego não mostrou predileção pelo jurídico, mas lançou as bases por onde circulariam as primeiras escolas romanas. [...]. De qualquer modo, e dado que as instituições teocráticas do direito penal não desapareceram de um só golpe, é bom que nos detenhamos no sentido de algumas delas, ainda que mais não seja, para demonstrar que aquilo que cremos "superado", frequentemente não faz mais do que transmutar-se, mudar a aparência, permanecendo o seu sentido político-penal. (ZAFFARONI; PIERANGELI, 2006, p. 163-164)."

\footnotetext{
${ }^{\dagger}$ A pesquisadora ressalva que havia a previsão da pena de exílio.

\# É cediço que Atenas tinha uma condição singular e que seria impossível um inventário sobre o direito em todas as cidades-estado. O fato é que houve uma evolução jurídica significativa na civilização grega, podendo ser apontados como herança o júri popular, a mediação, a arbitragem e a graduação das penas de acordo com a gravidade dos delitos. Para Fustel de Coulanges: "Procuramos descrever de maneira clara o regime social dos antigos em que a religião imperou como soberana absoluta na vida privada e na vida pública; em que o Estado era uma comunidade religiosa, o rei um pontífice, o magistrado um sacerdote, a lei uma fórmula santa; em que o patriotismo era pio e o exílio uma excomunhão; em que a liberdade individual era desconhecida e o homem estava sujeito ao Estado por alma, corpo e patrimônio; em que o ódio contra o estrangeiro se tornava obrigatório, e as noções de direito e de dever, de justiça e de afeto paravam nos limites da cidade; em que a associação humana se achava necessariamente encerrada em verdadeira circunferência em redor de um pritaneu, não se encontrando
} 
Em Roma já é possível a percepção de uma ciência penal propriamente dita. O progresso científico e o poderio bélico transformaram a cidade em um império de pujança e destruição. Tanto em Roma, essencialmente no período republicano, quanto na Grécia, a percepção era a de que a segurança do Estado estava em risco pela simples presença, nas adjacências, de outro Estado ou outros povos. Na lógica das guerras, "as conquistas se entrosam uma nas outras, pois o aumento das possessões multiplica os deveres defensivos e as ocasiões de conflito" (AYMARD; AYBOYER, 1993, p. 132).

Paradoxalmente, se a paz derivava da guerra, a prosperidade decorria de saques e da subjugação dos rebeldes, no exercício pleno e impiedoso do direito do vencedor. "Roma reivindicou respeito com base em uma superioridade de força. Os sentimentos que os romanos esperavam inspirar no inimigo eram temor e terror. [...]. A paz deveria ser solicitada por um

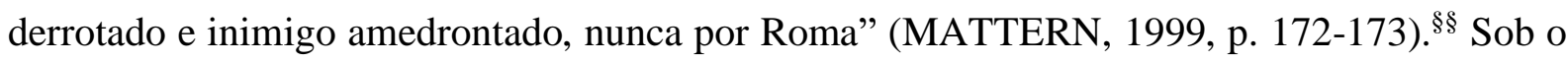
ponto de vista histórico, mais precisamente a Idade Moderna e o "Derecho Penal castellano", Francisco Tomás y Valiente leciona que

en este período, como en tantos otros de épocas más recientes, y de regímenes políticos fuertes, la ley penal y su complemento la jurisprudencia se convirtieron en instrumentos de resistência y de defensa del poder y del ordem establecidos, en mayor y más dura proporción de lo razonablemente admisible. (VALIENTE, 1969, p. 45).

Carl Schmitt, sob os auspícios do nacional-socialismo alemão, resgatou de forma explícita a categoria de inimigo: "Inimigo é somente o inimigo público, pois tudo o que se refere a um conjunto semelhante de pessoas, especialmente a todo um povo, se torna, por isso, público. Inimigo é hostis, não inimicus em sentido amplo; polemios, não echtros" (SCHMITT, 2009, p. 30). Esse hiato de quase dois séculos, para ser mais coerente com a derrocada do Antigo Regime, nunca interditou a função que o direito penal vem desenvolvendo com êxito desde os tempos mais remotos, uma vez que

[...] o hostis, inimigo ou estranho nunca desapareceu da realidade operativa do poder punitivo nem da teoria jurídico-penal (que poucas vezes o reconheceu abertamente e, quase sempre, o encobriu com os mais diversos nomes). Trata-se de um conceito que, na versão original ou matizada, de cara limpa ou com mil máscaras, a partir de Roma,

possibilidades de fundar sociedades mais amplas. Estes os traços característicos das cidades gregas e itálicas, durante o primeiro período da sua história. Mas, pouco a pouco, como vimos, a sociedade modificou-se. Introduziram-se modificações no governo e no direito, ao mesmo tempo que nas crenças. Nos cinco séculos que precederam o cristianismo, já não se manifestava tão íntima a união entre a religião, de um lado, e o direito e a política, do outro" (COULANGES, 1998, p. 150).

$\S \S$ "Rome claimed respect based on a superiority of force. The feelings that the Romans hoped to inspire in the enemy were awe and terror. (...). Peace was supposed to be requested by a defeated and frightened enemy, never by Rome" (MATTERN, 1999, p. 172-173). 
atravessou toda a história do direito ocidental e penetrou na modernidade, não apenas no pensamento de juristas como também no de alguns de seus mais destacados filósofos e teóricos políticos, recebendo especiais e até festejadas boas-vindas no direito penal. Trata-se de um elemento conceitual contraditório dentro do Estado de direito porque arrasta a semente de sua destruição, muito embora a sua incoerência só se tenha manifestado nos anos 30 do século passado, por obra da pena de Schmitt, o mais teórico político do nazismo. [...]. Para os teóricos - e sobretudo para os práticos - da exceção, sempre se invoca uma necessidade que não conhece lei nem limites. A estrita medida da necessidade é a estrita medida de algo que não tem limites, porque esses limites são estabelecidos por quem exerce o poder. (ZAFFARONI, 2007, p. 23-25)

Duas interpelações merecem registro. Em primeiro lugar, apesar da contextualização do século XX, a interpretação de inimigo como sendo somente o público reclama um adendo, pois, além de externo ${ }^{* * *}$, há o interno. Este é um dos aspectos centrais do problema. "Exemplo disso é a República Romana, invencível ante os inimigos e tantas vezes vencida e miseravelmente oprimida pelos seus cidadãos, em particular na guerra civil de Vespasiano contra Vitélio" (ESPINOSA, 2008, p. 254). Era comum os usurpadores do poder, a fim de garantir a segurança pessoal e a estabilidade do governo, vincular a sua imagem e origem aos deuses. Em segundo lugar, em que pese a importância irrefutável do direito romano para o Ocidente, não se pode olvidar que a noção de inimigo em sentido jurídico já estivesse no direito grego, de forma que a existência de uma teoria mais elaborada não legitima o pioneirismo de Roma.

O surgimento e consolidação do crimen laesae maiestatis ${ }^{\dagger \dagger \dagger}$ ocorreu oficialmente no direito penal romano no império de Augusto, no ano 8 a. C., por intermédio da Lex Iulia de maiestatis. "A expressão maiestas nasce na cultura política da Roma Antiga, em que designava o lugar supremo, a ordem superior que os súditos deveriam tratar com respeito e reverência" (COMTE-SPONVILLE, 2011, p. 65). O imperador passa a ser concebido como a personificação do próprio povo romano ${ }^{\dagger+}$ e inicia-se o longo itinerário que culminará com a

\footnotetext{
*** “O estrangeiro não é o inimigo. Para Caim, o inimigo é Abel, seu irmão. E, inversamente, o estrangeiro é muitas vezes tratado como amigo. Ulisses, em seu périplo, é algumas vezes muito bem recebido. A paixão pelo poder interno pode levar uma facção a considerar o estrangeiro como um amigo, sendo o inimigo a facção rival. [...]. Por outro lado, o estrangeiro, amigo ou inimigo, é um homem diferente e, consequentemente, com comportamento estranho, até imprevisível. É o homem que introduz o aleatório" (DUROSELLE, 2000, p. 49-50).

†† "Majestade (majesté) - Uma grandeza visível, que justificaria ao mesmo tempo o respeito e a obediência. É o que levava Alain a dizer que era 'inimigo de qualquer espécie de Majestade'. E dava esta definição perfeita: 'A Majestade é tudo o que, tendo o poder, ainda quer ser respeitado'. É querer reinar também sobre os espíritos. Toda majestade é ridícula ou tirânica" (COMTE-SPONVILLE, 2011, p. 359).

†+ "Uma divindade é uma entidade sobrenatural que se manifesta, sem dúvida, por uma acção sobre o mundo, mas que se situa para lá desta acção e a ultrapassa. Nunca uma cidade grega fora divinizada em si mesma; na época clássica, gostavam de ter uma divindade por símbolo, mas o corpo político dos cidadãos - o que, em Roma, é o populus - atingira esse grau de transcendência que lhe conferia uma dignidade eminente, a majestas, acima de todos os seres em particular. Foi Roma que não só impôs, mas (o que é ainda mais importante) formulou essa
} 
total confusão entre o corpo do soberano e o corpo do Estado e a perpetuidade da realeza. Nesta perspectiva, o crime de lesa-majestade é aquele cometido contra o povo romano ou contra a sua segurança e o seu autor, o inimigo político, eliminado. Conforme a lição de Eugenio Raúl Zaffaroni e José Henrique Pierangeli,

nos primórdios de Roma - como nos de qualquer povo primitivo - o direito penal teve uma origem sacra. Não obstante, a partir da Lei das XII tábuas (século V a. C.), o direito já se encontra laicizado e estabelece-se a diferença entre delitos públicos e privados. Os delitos públicos eram perseguidos pelos representantes do Estado, no interesse deste, enquanto os delitos privados eram perseguidos pelos particulares em seu próprio interesse. Não obstante, não se deve pensar que, nos delitos públicos incorporam-se apenas delitos contra o Estado. Os delitos públicos se formavam em torno de dois grandes delitos: o de perduellio e o de parricidium. Esses delitos são os pais dos dois grandes grupos de delitos: delitos contra o Estado e delitos contra os particulares. Recorde-se que o parricidium não é a morte do pai, e sim do "pater", isto é, do chefe da "gens", daquele que era considerado homem livre. Daí que os delitos públicos eram tanto os delitos contra os homens livres (mas somente naqueles em que o estado tinha interesse na persecução), quanto os delitos contra o próprio Estado. [...]. Posteriormente, os próprios delitos privados, ou seja, os cometidos contra os homens livres, e naqueles em que o Estado originariamente não tinha interesse em perseguir, passam a ser perseguidos pelo Estado e submetidos a pena pública por meio do chamado procedimento extraordinário, o qual termina convertendo-se em ordinário. Assim foi como o direito penal se afirmou em seu caráter público. Essa mudança tem lugar com o advento do Império. Durante a República, o povo romano havia sido simultaneamente legislador e juiz, permanecendo como delitos privados (liberada a composição entre as partes) somente os mais leves. Paulatinamente, se foi entregando a faculdade de julgar às Quaestiones, que o faziam por "exigências da majestade do povo romano" e da "saúde da coisa pública", o que estava bem distante da concepção teocrática oriental. $\mathrm{O}$ direito penal romano fundava-se, assim, no interesse do Estado. [...]. Com o advento do Império, afirma-se a publicidade do direito penal mediante o procedimento extraordinário, constituído por tribunais que atuavam por delegação do Imperador. O Império foi corrompendo as instituições republicanas e o procedimento extraordinário converte-se em jurisdição ordinária, em razão de que o âmbito dos crimes majestatis (crimes contra a majestade, contra a soberania do imperador) se foi ampliando cada vez mais. Esse é um fenômeno que se pode observar em quase toda a história posterior da legislação penal: enquanto com a afirmação do caráter público do direito penal não se disse nada acerca da natureza jurídica dos bens tutelados, quando sobrevém um período imperialista, não só se faz pública a tutela dos bens, como também os próprios bens passam a ser públicos. Já não se trata de bens particulares que são tutelados pelo Estado, mas se passa a considerar que os próprios bens pertencem ao Estado. $\mathrm{O}$ direito penal não é mais que um instrumento a serviço dos interesses do Estado. Já não haverá interesses particulares tutelados publicamente, mas todos os interesses serão públicos. No caso de Roma, pode-se concluir que o direito penal de Justiniano é a "expressão do princípio de que a conservação do Estado é o fundamento da punição. (ZAFFARONI; PIERANGELI, 2006, p. 165-166).

Susan P. Mattern apresenta uma outra acepção para o conceito de inimigo. Ao abordar a relação entre Roma e Pártia, ela enfatiza que “esta palavra superbia também é usada em outros lugares para descrever os inimigos de Roma, como um argumento para a guerra” (MATTERN,

noção até então desconhecida e que, ao mesmo tempo, proporcionou a todos os cidadãos a esperança de participarem na cidade divina" (GRIMAL, 2018, p. 311). 
1999, p. 175). Superbia, etimologicamente, é um nome feminino italiano, o qual significa soberba, orgulho, arrogância, altivez. A simbiose procede. Tomás de Aquino recorda a regra do superior: "Nisso está o pecado de soberba: não se submeter ao superior naquilo que lhe é devido. Por isso, o primeiro pecado do anjo só pode ser de soberba" (AQUINO, 2005, p. 240). A deflagração da guerra, muitas vezes, não adotada um protocolo econômico ou geopolítico.

A conquista não se resumia ao equilíbrio do orçamento ou à ampliação de terras férteis sob o seu domínio. A vingança e a retaliação ocupavam papel de relevo no conjunto das iniquidades. Para além de questões puramente materiais, o triunfo transportava consigo elementos psicológicos: a necessidade de reprimir a superbia do inimigo e manter a honra ou decus do império. A glória reforçava o temor e o prestígio das outras civilizações. Àqueles que ousaram sucumbir Roma, eles reafirmaram com a máxima brutalidade a sua máquina de produzir cadáveres.

\section{O inimigo na Idade Média}

A Idade Média foi um longo período da história da Europa que se estendeu do século $\mathrm{V}$ ao século XV. Seu início foi marcado pela queda do Império Romano do Ocidente, em 476 d. C., e do Oriente, em 1453, com a tomada de Constantinopla pelos turcos. O poder da Igreja foi inversamente proporcional ao poder de Roma. No auge da potestade, os imperadores convocavam os tribunais eclesiásticos, examinavam a aplicação das leis canônicas e controlavam a administração dos bens da Igreja. Entretanto, com o declínio da autoridade civil e, principalmente, ao longo do século IV, o catolicismo se tornou a religião oficial do Império Romano. Com isso, a Igreja percorreu os últimos séculos da Antiguidade gozando de relativo poder.

No período medieval, a continuidade do processo de expansão religiosa se estendeu às populações bárbaras que invadiram os domínios romanos e consolidaram novos reinos. Entre esses reinos, destacamos o Reino dos Francos, onde se instituiu uma íntima relação entre os membros do clero e as autoridades políticas. A partir de então, a Igreja passou a acumular vultosas quantidades de terras e a exercer influência sobre grupos cada vez maiores de fiéis. Da comunhão entre Estado e Igreja surgiu o Sacro Império Romano, tendo como primeiro Imperador Carlos Magno, coroado pelo papa Leão III em 800. Desde 774 ele já era Rei dos Lombardos e, desde 768, Rei dos Francos. 
Em 1796, em carta ao Pontífice que o coroou quatro anos após, Carlos Magno reivindicou para a sua autoridade a “função não somente de 'defender com as armas' a Igreja de seus inimigos externos, mas também a de 'fortificá-la no seu interior através do maior conhecimento da fé católica"” (FERRARI, 1998, p. 163). Nesta perspectiva se inscrevem as cruzadas sugeridas contra os infiéis e a repressão contra a heresia. O Império Carolíngio (800924), homenagem ao seu nome, foi sucedido, com a coroação de Otão I, pelo Sacro Império

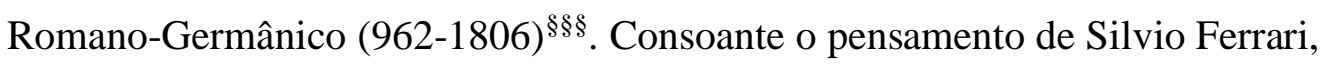

\begin{abstract}
a tentativa mais séria de dar vida a um modelo político-teocrático deu-se entre o final do século XI e o início do século XIV, por obra do papado. A ideia de uma subordinação necessária da Civitas terrena à Civitas collestis, isto é, do Estado à Igreja, foi já difundida no pensamento patrístico e foi teorizada por Santo Agostinho no De civitate Dei. Entretanto, somente na Idade Média é que condições históricas concretas permitiram à Igreja dar um desenvolvimento orgânico à instituição augustiniana e tentar uma atuação prática. Na queda do Império Romano e nos anos obscuros de dominação dos bárbaros, na verdade, a Igreja apareceu como a única instituição realmente universal, bem mais forte do que o Império Romano do Ocidente, que bem depressa seria lacerado pelos conflitos entre os Estados Nacionais que dentro dele se foram formando. Isso conduziu rapidamente ao esquecimento da concepção tradicional, segundo a qual sacerdotium e imperium têm igualmente origem em Deus para bem da humanidade. (FERRARI, 1998, p. 1237).
\end{abstract}

Do ponto de vista histórico-jurídico, a derrocada do Império Romano provocou substanciais alterações no direito medieval. A desagregação política produziu o pluralismo jurídico. Os comentadores ou práticos do direito, na construção da futura modernidade

\footnotetext{
$\$ \$ \$$ Segundo Paolo Grossi, "A chave interpretativa essencial de toda a ordem jurídica medieval - aquela que nos cabe sublinhar ao leitor - é que os detentores do poder constituem uma fonte entre as muitas chamadas a edificar essa ordem. [...]. As 'leis' - ou seja, os atos de autoridade gerais e rígidos, destinados a todos os súditos ou a uma parte considerável deles - não faltam nem mesmo no primeiro período medieval. Os monarcas visigodos na Espanha e os lombardos na Itália, no comando de reinos que por muitos séculos constituíram um regime estável, respectivamente, em toda a península Ibérica e em boa parte da Itália centro-setentrional (séculos VI-VIII), empenharam-se numa constante atividade legislativa" (GROSSI, 2014, p. 67-68). Por outro lado, Marc Bloch advertiu: "Explica-se, por essa carência de instrução na vida secular, o papel dos clérigos, ao mesmo tempo, como intérpretes do pensamento dos grandes e como depositários das tradições políticas. [...]. O mesmo ocorreu, em geral, em outros lugares. Não se poderia considerar indiferente o fato de que as decisões dos poderosos desse mundo tenham, por vezes, sido sugeridas e sempre expressas por homens que, a despeito de suas posições de classe ou de nação, não deixavam de pertencer, por toda sua educação, a uma sociedade de natureza universalista e fundada no espiritual. Não há dúvida de que tenham contribuído para manter, acima, da confusão dos pequenos conflitos locais, a preocupação com alguns horizontes mais amplos. Por outro lado, encarregados de dar forma escrita aos atos da política, viram-se necessariamente levados a justificá-los oficialmente por motivos extraídos de seu próprio código moral e a espalhar, dessa forma, sobre os documentos de quase toda a era feudal, esse verniz de considerandos mais do que parcialmente enganadores, como atestam, em particular, os preâmbulos de tantas emancipações feitas por dinheiro, travestidas em puras liberalidades, ou tantos privilégios reais, que se queriam ditados, uniformemente, pela piedade mais banal. Como, por muito tempo, também a historiografia, com seus julgamentos de valor esteve nas mãos dos clérigos, as convenções de pensamento, tanto quanto as literárias, conspiraram para tecer, diante da realidade cínica dos motivos humanos, uma espécie de véu que não seria definitivamente rasgado, no limiar de novos tempo, senão pela mãos firme de um Commynes e de um Maquiavel" (BLOCH, 2016, p. 99-100).
} 
europeia, converteram o direito justinianeu em um direito comum de todo o continente (ius commune). O ius commune romano estava em constante diálogo com o ius speciale local. Como realçou Franz Wieacker, "só pela sua mão a velha ideia de que o direito romano era a ratio scripta da cristandade ocidental se tornou uma realidade palpável” (WIEACKER, 2015, P. 80).

O mérito na compreensão de toda a realidade jurídica englobava o domínio da técnica de aplicação do corpo prático do direito, ou seja, do discernimento sobre o direito comum, os costumes locais e as instituições da Alta e Baixa Idade Média. “Quando o jurista 'prático' encontrou um modus arguendi na parafernália lógica disponível, ele usou um dispositivo incluído no Corpus iuris civilis ou nas leis universais da Igreja como o eixo de seu argumento" (BELlOMO, 1995, p. 154).**** Conforme o magistério de Gustavo César Machado Cabral,

\begin{abstract}
Não houve um impasse entre a existência de um direito comum, fundado primordialmente na opinio communis doctorum, e o fortalecimento da autoridade régia. Isso se deu justamente porque uma das facetas do ius commune foi a convivência com os ordenamentos jurídicos particulares, dentre os quais o direito pátrio, da mesma forma que o direito pátrio foi absorvendo o direito comum, principalmente em matérias de direito privado, mas também em matérias de direito público, quando as categorias romanas a que aludiram os doutores continuavam a ser empregadas nos reinos europeus. (CABRAL, 2017, p. 38-39)
\end{abstract}

A grande presença do catolicismo durante o Medievo começou a sofrer um expressivo abalo quando os movimentos heréticos da Baixa Idade Média e, séculos depois, o Movimento Protestante, questionaram o monopólio religioso e intelectual de seus clérigos. Nesse contexto, a Igreja reafirmou suas concepções de fé por meio da Contrarreforma, a instalação da Inquisição e a expressiva participação na conversão das populações nativas encontradas no continente americano. A reforma protestante, ao contribuir para a ruptura da unidade religiosa na Europa, significou o ocaso do sistema teocrático em sentido amplo, pelo menos sob o ponto de vista do Ocidente.

Em relação ao crime de lesa-majestade, não houve uma produção legislativa substancial até o século XI. Nos dois séculos subsequentes houve uma evolução gradual no território europeu. Todavia, a partir do século XIV, a produção dos juristas italianos na matéria irradiouse por toda a Europa, com destaque para o Fuero Real, de 1255, e as Siete Partidas, de 1265, ambas emanadas pelo rei Alfonso X. Para Arno Dal Ri Júnior, "nos primeiros momentos da Baixa Idade Média, este delito demonstrava-se revestido de uma conotação moral e não

\footnotetext{
***** "When the 'practical' jurist found an adequate modus arguendi in the available logical paraphernalia, e used a disposition included in the Corpus iuris civilis or in the universal laws of the church as the linchpin of his argument" (BELLOMO, 1995, p. 154).
} 
fundamentado na lesão de um bem jurídico (a segurança do Estado), como aconteceu nos ordenamentos de matriz liberal" (RI JÚNIOR, 2005, p. 97). que fundaram o Estado Moderno. Contudo, como delito mais grave e odioso, em paulatina, mas contínua expansão, o receio com a segurança do Estado e, por conseguinte, o exercício do poder, sempre esteve, direta ou indiretamente, presente no imaginário do déspota.

\title{
4. A cultura penal na Idade Moderna: o sistema penitenciário e a polícia
}

O crime de lesa majestade prosseguiu em expansão em virtude do processo de organização dos Estados europeus. A autoridade da Coroa reclamava fortalecimento e reafirmação. "O crime de lesa majestade era, sem dúvida, uma das condutas mais graves do Medievo e do Antigo Regime, sendo provavelmente a que recebia punições mais graves" (CABRAL, 2016, p. 55)..$^{\dagger \dagger}$ Foi nesse contexto de preocupação com a proteção do poder político do soberano contra qualquer tentativa de desestabilização que o crime de lesa majestade se consolidou como um instrumento fundamental para a manutenção da ordem interna, coibindo revoltar e exercendo, em larga medida, um forte controle social sobre os súditos.

Em relação à acusação contra Domenico Scandella ("Menoccio"), moleiro do norte da Itália, no século XVI, Carlo Ginzburg esclarece que o chefe supremo dos católicos, o papa em pessoa, Clemente VIII, se inclinava sobre Menocchio, que se tornara um membro infectado do corpo de Cristo, e exigia expressamente a sua morte. Tendo este processo como premissa, ele afirmou que

\begin{abstract}
uma cultura quase exclusivamente oral como a das classes subalternas da Europa préindustrial tende a não deixar pistas, ou então deixar pistas distorcidas. Portanto, há um valor sintomático num caso-limite como o de Menocchio. Ele repropõe, com força, um problema cuja importância só agora se começa a perceber: as raízes populares de grande parte da alta cultura europeia, medieval e pós-medieval. [...]. Todavia, fecharam uma época caracterizada pela presença de fecundas trocas subterrâneas, em
\end{abstract}

\footnotetext{
†† Sobre as Ordenações Filipinas: "O exercício da justiça seguia no mesmo caminho, fazendo privilegiar a vontade do monarca sobre a vingança particular, tornando pública a justiça penal. Punir, controlar os comportamentos e instituir uma ordem social, castigar as violações a essa ordem e afirmar o poder do soberano constituem elementos inerentes ao poder real. Para ser eficaz, portanto, a punição devia ser afirmativa e exemplar: como exercício de poder, ela devia explicitar a norma, fazer-se inexorável e suscitar temor. Não é por outra razão que as punições no Antigo Regime transformavam-se em espetáculo, em pedagogia capaz de atingir o corpo do criminoso e, principalmente, impressionar os sentidos dos demais súditos e vassalos. O lugar onde era construído o patíbulo, a escolha do dia da execução e do roteiro por onde passaria o cortejo penal, a distribuição dos lugares a serem ocupados pelos membros da nobreza, milícias etc. - tudo fazia do ritual punitivo uma cerimônia política, de reativação do poder e da lei do monarca. O suplício penal fazia-se proporcional à ofensa cometida contra o soberano e sua lei; ao efetivar-se contra o corpo do condenado (marcando-o, quebrando-o e subjugando-o fisicamente), explicitava o triunfo e a glória reais" (LARA, 1999, p. 21).
} 
ambas as direções, entre a alta cultura e a cultura popular. [...]. Então, se impôs às classes dominantes, de maneira dramática, a necessidade de recuperar, mesmo ideologicamente, as massas populares que ameaçavam escapar a qualquer forma de controle vindo de cima - porém mantendo e até acentuando as distâncias sociais. Esse renovado esforço de obter hegemonia assumiu formas diversas nas várias partes da Europa; mas a evangelização do campo por obra dos jesuítas e a organização religiosa capilar baseada na família, executada pelas igrejas protestantes, podem ser agrupadas numa mesma tendência. A ela correspondem, em termos de repressão, a intensificação dos processos contra a bruxaria e o rígido controle dos grupos marginais, assim como dos vagabundos e ciganos. $\mathrm{O}$ caso de Menocchio se insere nesse quadro de repressão e extinção da cultura popular. (GINZBURG, 2006).\$+\$

Na história social do crime e do direito, a "Lei 9 Jorge I c. 22", mais conhecida como Lei Negra, é uma referência. Aprovada pelo parlamento inglês em maio de 1723, ela criminalizou mais de cinquenta condutas com a pena de morte, entre as quais caçar veados, derrubar árvores ou cultivar a agricultura de subsistência nas terras da Coroa e dos latifundiários, localizadas, em regra, nas cercanias de Londres (Windsor e Hampshire). Além disso, a lei chancelou a possibilidade do preso ser julgado e processado em qualquer condado da Inglaterra, sendo um irrelevante processual o local de cometimento do suposto delito. À época, "el estado británico existía - todos los legisladores del siglo XVIII estaban de acuerdo en eso - para proteger la propiedad y, eventualmente, las vidas y libertades de los propietarios" (THOMPSON, 2010, p. 23).

O ineditismo da lei consiste exatamente em penalizar a transgressão com a pena capital em um período no qual o seu recurso encontrava-se em declínio. Esta fase reflete a transição da sociedade camponesa- medieval para a sociedade burguesa-industrial. O trabalhador "fora da lei”, forjado pelo sistema de produção, passa a fazer parte das estatísticas do banditismo social, da vagabundagem e da delinquência. O êxodo rural e as revoltas camponesas intensificam a luta de classes nas cidades. Neste sentido, leciona Dario Melossi:

A tendência histórica que não muda - ao contrário, é consolidada e afirmada nesse
período - é a substituição das velhas penas corporais e de morte pela detenção. Uma
detenção, todavia, cada vez mais inútil e dolorosa para os internos. [...]. A raiz dessa
progressiva decadência deve ser buscada nas grandes transformações ocorridas na
segunda metade do século XVIII. Uma excepcional aceleração do ritmo do
desenvolvimento econômico, o fenômeno da Revolução Industrial, rompe com todos
os tradicionais equilíbrios sociais precedentes. Uma repentina inclinação da curva do
crescimento demográfico, juntamente com a introdução das máquinas e a passagem
do sistema manufatureiro para o sistema de fábrica propriamente dito, servem para

+सt “A melhor maneira de abordar as ideias relativistas ou universalistas entre a população cristã-velha é examinálas nos grupos tidos e descritos como contrários à verdadeira fé. Uma preocupação constante da Igreja e do Estado durante grande parte desse período foi definir os não católicos ou os falsos católicos como indivíduos não só condenados teologicamente mas também politicamente perigosos. O efeito disso foi criar uma larga base de suspeita, rejeição e por vezes aversão fanática a esses grupos. Tais ódios duraram por muito tempo" (SCHWARTZ, 2009, p. 126). 
assinalar contemporaneamente a idade de ouro do jovem capitalismo, acompanhado pelo período mais escuro da história do proletariado. A incrível aceleração da penetração do capital no campo e, concomitantemente, a expulsão da classe camponesa, em especial através dos bills for inclosures of commons, as leis para os cercamentos das terras comunais, contribui para levar ao mercado de trabalho uma oferta de mão-de-obra sem precedentes. [...]. Os fenômenos do urbanismo, do pauperismo e da "criminalidade" crescem numa intensidade até então desconhecida. A "silenciosa coação das relações sociais" substitui a violência do regulamento. Ingressa-se na era do liberalismo, quando o capital, agora capaz de caminhar sobre suas próprias pernas, proclama-se orgulhosamente seguro de si mesmo e, autosuficiente, zomba do sistema de privilégios, desigual e autoritário, que nos séculos anteriores o havia alimentado. (MELOSSI, 2006, p. 64).

A Lei Negra não foi um fato isolado na Europa. Traduziu, de forma inapelável, a relação intrínseca entre a economia, a política e o direito. Exprimiu, no plano normativo, as tensões e contradições que caracterizavam a existência das classes sociais da sociedade pré-capitalista. Na Inglaterra, séculos XV e XVI, sob a égide do mercantilismo, a grande maioria dos crimes era punível com a pena de morte. ${ }^{\S \S \S} \mathrm{O}$ instituto da fiança, as deportações e os castigos corporais constituíam as exceções. Em relação às punições físicas, elas seguiam uma liturgia, com dois objetivos definidos. Em primeiro lugar, deveria deixar remanescente no corpo do condenado os sinais de sua transgressão contra a autoridade. Além desta característica, os suplícios precisavam ser não apenas públicos, mas notórios. Assim sendo, com a expiação da culpa, por intermédio dos gritos e gemidos do ser que jaz ao solo, a "justiça" manifestava a sua força, a sua potência. "Esse cerimonial meticuloso é, de uma maneira muito explícita, não só judicial, mas militar. A justiça do rei mostra-se como uma justiça armada. O gládio que pune o culpado é também o que destrói os inimigos" (FOUCAULT, 2000, p. 43).

É neste contexto que, na transição entre os séculos XVI e XVII, surgem, como modalidade de punição, as casas de trabalho, conhecidas também como casas de correção. "O trabalho era praticado na cela ou no grande pátio central, segundo a estação do ano. Tratava-se de uma aplicação do modelo produtivo então dominante: a manufatura" (MELOSSI, 2006, p. 43). A instalação desta segregação punitiva almejou a reforma dos internos por intermédio da

\footnotetext{
§§§ “No todo, o sistema era substantivamente uma expressão de sadismo, e o efeito dissuasivo do ato público era negligenciável. Esta a razão por que a imaginação mais mórbida de hoje tem dificuldade em descrever a variedade de torturas infligidas. Lemos acerca de execuções por faca, machado e espada, cabeças sendo golpeadas com toras ou cortadas com arado, pessoas sendo queimadas vivas, deixadas a morrer de fome em porões, ou tendo espinhos cravados em suas cabeças, olhos, ombros e joelhos, estrangulamentos e asfixiamentos, sangramentos e desvisceramentos até a morte, estiramentos do corpo até o esquartejamento, tortura sobre a roda, tortura com pinças incandescentes, descolamento da pele, corpos serrados em pedaços ou atravessados com ferro ou instrumentos de madeira, queimaduras na estaca e muitas outras formas elaboradas de crueldade. Não é de se estranhar que praticamente todos os crimes eram puníveis com a morte, e que a questão vital era a maneira pela qual a morte seria infligida" (RUSCHE; KIRCHHEIMER, 2004, p. 40-41).
} 
disciplina e do trabalho obrigatório. À época, o trabalho era desenvolvido no ramo têxtil, em virtude de sua ascensão dentro do sistema capitalista; isto é: o trabalhador era impelido a aceitar qualquer trabalho, em quaisquer condições. No tocante ao trabalho forçado nas houses of correction ou bridewells, Georg Rusche e Otto Kirchheimer consignam:

Os métodos de punição começaram a sofrer uma mudança gradual e profunda em fins
do século XVI. A possibilidade de explorar o trabalho de prisioneiros passou a receber
crescentemente mais atenção, com a adoção da escravidão nas galés, deportação e
servidão penal através de trabalhos forçados; as duas primeiras por um certo tempo, a
terceira como precursora hesitante de uma instituição que tem permanecido até o
presente. Algumas vezes elas apareceram simultaneamente com o sistema tradicional
de fianças e penas capital e corporal; em outras, tenderam a substituí-lo. Essas
mudanças não resultaram de considerações humanitárias, mas de um certo
desenvolvimento econômico que revelava o valor potencial de uma massa de material
humano completamente à disposição das autoridades. (RUSCHE; KIRCHHEIMER,
2004, p. 43).

$\mathrm{Na}$ Holanda, França e Inglaterra, países nos quais as casas de correção atingiram o apogeu em matéria de desenvolvimento, a composição dos internos abrangeu, em regra, desempregados e autores de crimes de menor porte, a exemplo do furto. Saliente-se, por oportuno, que a "manufatura recrutava a sua força de trabalho essencialmente em dois grupos sociais que tinham sido arruinados pelo desenvolvimento do capitalismo, dois tipos de pequenos produtores: os ex-artesãos e ex-camponeses” (MELOSSI, 2006, p. 45).

Os trabalhadores alheios a esse processo ficavam, portanto, extremamente vulneráveis à segregação como forma de controle social e a exercer o trabalho forçado como técnica de punição. "Os pobres, os jovens, as mulheres prostitutas enchem, no século XVII, as casas de correção. São eles as categorias sociais que devem ser educadas ou reeducadas na laboriosa vida burguesa, nos bons costumes" (MELOSSI, 2006, p. 55). Com efeito,

Sempre existiram pobres, miseráveis, deserdados. Do camponês do Egito antigo aos beduínos do deserto, do servo da Idade Média ao pequeno comerciante chinês, a grande massa da população sempre viveu em situação de indigência. Mas há pobres e pobres. Ao lado da grande massa composta por camponeses, artesãos, pescadores e criadores de animais que viviam modestamente e sem grandes bens, havia outro mundo, ainda mais necessitado: o dos párias, dos mendigos e miseráveis que não tinham nem terra, nem animais, nem lar, e que se viam obrigados a viver de mendicidade ou de rapina. [...]. A industrialização trouxe consigo um novo tipo de empobrecimento no Ocidente. No século XIX, a condição das classes proletárias era marcada pela precariedade, pelo ritmo infernal nas fábricas, pela insalubridade das moradias. [...]. Observa-se que a fragilidade econômica vem acompanhada de uma desagregação social. Nos bairros mal-afamados onde os proletários se amontoam, a miséria caminha lado a lado com a delinquência, a prostituição, o alcoolismo, a violência e as famílias desagregadas. (DORTIER, 2010, p. 494-495).

Por outro lado, a expressão "classes perigosas" foi empregada pela primeira vez em 1840, na obra Des classes dangereuses de la population dans les grandes villes et des moyens 
de lês rendre meilleeures. Seu autor, Honore-Antoine Frégier (1789-1860), foi delegado de polícia na zona do Sena, Paris. Conforme a sua idiossincrasia, os pobres e as classes viciosas são e sempre serão o núcleo para a proliferação de malfeitores de toda sorte; por terem propensão ao crime, classes perigosas que são, devem ser destinatárias de rígidos protocolos de prevenção, vigilância e sanção penal. Neste contexto, a polícia foi e permanece sendo uma das principais agências de controle social. A propósito, Eugenio Raúl Zaffaroni recorda que:

El positivismo retomo el discurso inquisitorial, en especial el centroeuropeo, arropando las ramas de esse árbol, que em su origen medieval cubrián los ejércitos de diablos, com el follaje de los incontables signos de degenaración o infrahumanidad biológica del evolucionismo racista, tan ingênuo como burdo. Cuando al promediar el siglo XIX la burguesia europea se asentó en el poder, el discurso liberal dejó de ser funcional a sus interesses; necesitaba outro, que legitimasse su hegemonia pero que, al mismo tempo, consolidase la nueva agencia que había surgido con la revolución industrial: la policía. (ZAFFARONI, 2005, p. 142).

A gênese da polícia no Antigo Regime teve como propósito funcionar como instância de controle formal perante o frenético processo de industrialização e de urbanização da sociedade. "Primordialmente, considera-se que a polícia não é simplesmente uma instituição do Estado, mas sempre de um determinado Estado" (RAMIREZ, 2015, p. 92). Consoante o pensamento de Airton Cerqueira-Leite Seelaender, a polícia, no contexto da restauração da ordem da Coroa, deveria combater "práticas e vícios contrários aos valores tradicionais de roupagem cristã (jogo, bebida, prostituição, bigamia, desonestidade no comércio, sedução de freiras)" (SEELAENDER, 2010, p. 197). Dentro da lógica do sistema de transição do modo de produção econômica, a sintonia entre a polícia e o cárcere foi perfeita: uma recolhe, outro segrega.

\section{Considerações finais.}

Em todas as épocas, nos princípios e nas práticas penais, a política está sempre presente. Longe de ser aleatório, o catálogo de crimes possui função e destinatários específicos. Neste sentido, é perfeitamente admissível uma concepção de inimigo sob a ótica do direito penal. Na Antiguidade clássica e no medievo, o inimigo era evidentemente representado pelo sujeito ativo do crime de lesa majestade.

Esta construção, reforçada no início e apogeu do Estado Moderno, sofreu uma transmutação em face das transformações do modo de produção desencadeado pelo précapitalismo. Nesta perspectiva, defende-se que o inimigo do Estado, na segunda metade do 
século XVIII, com a polícia e o sistema penitenciário, passam a ser as pessoas economicamente vulneráveis. Com a laicização, a Revolução Industrial, a urbanização e o êxodo rural, o Estado não mediu esforços para preservar a conveniência e os interesses das classes dominantes. A prisão é uma escolha política, um produto da modernidade.

\section{Referências}

AQUINO, Tomás de. Suma teológica: a criação, o anjo, o homem. 2. ed. Tradução de Aldo Vannucchi et. al. São Paulo: Edições Loyola, 2005. v. II.

AYMARD, André; AYBOYER, Jeannine. Roma e seu império: o Ocidente e a formação da unidade mediterrânea. Tradução de Pedro Moacyr Campos. Rio de Janeiro: Editora Betrand Brasil S.A., 1993. v. III.

BELLOMO, Mantio. The common legal past of Europe: 1000-1800. Translated by Lydia G. Cochrane. Washington, D.C.: The Catholic University of America Press, 1995.

BLOCH, Marc. A sociedade feudal. Tradução de Laurent de Saes. São Paulo: Edipro, 2016.

CABRAL, Gustavo César Machado. Direito penal na literatura de Decisiones em Portugal (1578-1660). El derecho penal en la edad moderna: nuevas aproximaciones a la doctrina y a la práctica judicial. Madrid: Editorial Dykinson, 2016. p. 23-76.

Literatura jurídica na Idade Moderna: as decisiones no reino de Portugal (séculos XVI e XVII). Rio de Janeiro: Lumen Juris, 2017.

COMTE-SPONVILLE, André. Majestade. In: Dicionário filosófico. 2. ed. Tradução de Eduardo Brandão. São Paulo: Martins Fontes, 2011. p. 359.

COUlAngES, Fustel de. A cidade antiga. Tradução de Fernando de Aguiar. São Paulo: Martins Fontes, 1998.

DORTIER, Jean-François. Pobreza. In: Dicionário de ciências humanas. Tradução de Aline Saddi Chaves et. al. São Paulo: Martins Fontes, 2010. p. 494-495.

DUROSELLE, Jean-Baptiste. Todo império perecerá: teoria das relações internacionais. Tradução de Ane Lize Spaltemberg de Seiqueira Magalhães. Brasília: Editora Universidade de Brasília; São Paulo: Imprensa Oficial do Estado, 2000.

DAL RI JÚNIOR, Arno. O Estado e seus inimigos: a repressão política na história do direito penal. Rio de Janeiro: Revan, 2006. 
O processo de ressignificação do crimen laesae maiestatis na cultura penal da Idade Média. In: LUPI, João; Ed. Unijuí, 2005. p. 79-100. (orgs.). Humanismo medieval: caminhos e descaminhos. Ijuí:

ESPINOSA, Baruch de. Tratado teológico-político. Tradução de Diogo Pires Aurélio. São Paulo: Martins Fontes, 2008.

FERRARI, Silvio. Cesaropapismo. In: BOBBIO, Norberto; MATTEUCCI, Nicola.; PASQUINO, Gianfranco. Dicionário de política. 11. ed. Tradução de Carmen C. Varriale et. al. Brasília: Editora Universidade de Brasília, 1998. p. 162-163. v. 1.

. Teocracia. In: BOBBIO, Norberto; MATTEUCCI, Nicola.; PASQUINO, Gianfranco. Dicionário de política. 11. ed. Tradução de Carmen C. Varriale et. al. Brasília: Editora Universidade de Brasília, 1998. p. 1.237-1.238. v. 2.

FOUCAULT, Michel. Vigiar e punir: nascimento da prisão. 22. ed. Tradução de Raquel Ramalhete. Petrópolis: Vozes, 2000.

GARLAN, Yvon. L'uomo e la guerra. In: VERNANT, Jean-Pierre (a cura di). L'uomo greco. Roma-Bari: Laterza, 2012. p. 66-143.

GINZBURG, Carlo. O queijo e os vermes: o cotidiano e as ideias de um moleiro perseguido pela Inquisição. Tradução de Maria Betânia Amoroso. São Paulo: Companhia das Letras, 2006.

GIRARD, René. A violência e o sagrado. 3. ed. Tradução de Martha Conceição Gambini. São Paulo: Editora Universidade Estadual Paulista, 1990.

GRIMAL, Pierre. A civilização romana. Tradução de Isabel St. Aubyn. Lisboa: Edições 70, 2018.

O teatro antigo. Tradução de António M. Gomes da Silva. Lisboa: Edições 70, 1986.

GROSSI, Paolo. A ordem jurídica medieval. Tradução de Denise Rossato Agostinetti. São Paulo: Martins Fontes, 2014.

HUGO, Victor-Marie. O último dia de um condenado. 3 ed. Tradução de Joana Canêdo. São Paulo: Companhia das Letras, 2010.

JAPIASSÚ, Hilton; MARCONDES, Danilo. Teocracia. Dicionário básico de filosofia. 4. ed. Rio de Janeiro: Jorge Zahar Editor, 2006. p. 265.

LARA, Silvia Hunold. Introdução. In: (org.). Ordenações filipinas: livro V. São Paulo: Companhia das Letras, 1999. p. 19-44.

MATTERN, Susan P. Rome and the enemy: imperial strategy in the principate. California: University of California Press, 1999. 
MELOSSI, Dario. A gênese da instituição carcerária moderna na Europa. In: PAVARINI, Massimo. Cárcere e fábrica: as origens do sistema penitenciário (séculos XVIXIX). Tradução de Sérgio Lamarão. Rio de Janeiro: Revan; Instituto Carioca de Criminologia, 2006. p. 29-147.

NEUMANN, Franz. Behemoth: the structure and practice of national socialism, 1933-1944. Washington: United States Holocaust Memorial Museum; Chicago: Ivan R. Dee, 2009.

RAMIREZ, Juan Bustos. O controle formal: polícia e justiça. In: Roberto Bergalli et. al. (org.). O pensamento criminológico II: estado e controle. Tradução de Roberta Duboc Pedrinha e Sérgio Chastinet Duarte Guimarães. Rio de Janeiro: Revan, 2015. p. 91-135.

RUSCHE, Georg; KIRCHHEIMER, Otto. Punição e estrutura social. 2 ed. Tradução de Gizlene Neder. Rio de Janeiro: Instituto Carioca de Criminologia; Revan, 2004.

SCHMITT, Carl. O conceito do político/Teoria do Partisan. Tradução de Geraldo de Carvalho. Belo Horizonte: Del Rey Editora, 2009.

SCHWARTZ, Stuart B. Cada um na sua lei: tolerância religiosa e salvação no mundo atlântico ibérico. Tradução de Denise Bottman. São Paulo: Companhia das Letras; Bauru: Edusc, 2009.

SEELAENDER, Airton Cerqueira-Leite. Estado de polícia. In: BARRETO, Vicente de Paulo (coord.). Dicionário de filosofia política. São Leopoldo, RS: Editora Unisinos, 2010. p. 196199.

SILVA, Kalina Vanderlei; SILVA, Maciel Henrique. Religião. In: Dicionário de conceitos históricos. 3. ed. São Paulo: Contexto, 2018. p. 354-358.

SOUZA, Marcos Antônio de. O direito hebraico antigo. In: WOLKMER, Antonio Carlos (org.). Fundamentos de história do direito. 8. ed. Belo Horizonte: Del Rey Editora, 2015. p. 45-76.

SOUZA, Raquel de. O direito grego antigo. In: WOLKMER, Antonio Carlos (org.). Fundamentos de história do direito. 8. ed. Belo Horizonte: Del Rey Editora, 2015. p. 77- 111.

THOMPSON, Edward Palmer. Los orígenes de la ley negra: um episodio de la historia criminal inglesa. Traducción de Teresa Beatriz Arijón. Buenos Aires: Siglo Veintiuno Editores, 2010 .

TOMÁS Y VALIENTE, Francisco. El derecho penal de la Monarquía absoluta (Siglos XVI - XVII). Madrid: Editorial Tecnos, 1969.

TUCÍDIDES. História da Guerra do Peloponeso. 4. ed. Tradução de Mário da Gama Kury. Brasília: Editora Universidade de Brasília, Instituto de Pesquisa de Relações Internacionais; São Paulo: Imprensa Oficial do Estado de São Paulo, 2001.

VERNANT, Jean-Pierre Vernant. Mito e religião na Grécia Antiga. Tradução de Joana Angélica D’ Avila Melo. São Paulo: Martins Fontes, 2009. 
WIEACKER, Franz. História do direito privado moderno. 5. ed. Tradução de António Manuel Botelho Hespanha. Lisboa: Fundação Calouste Gulbenkian, 2015.

ZAFFARONI, Eugenio Raúl; PIERANGELI, José Henrique. Manual de direito penal brasileiro: parte geral. 8 ed. São Paulo: Editora Revista dos Tribunais, 2006. v. I.

Las "clases peligrosas": el fracaso de un discurso policial prepositivista. Sequência: Revista do Curso de Pós-Graduação em Direito da Universidade Federal de Santa Catarina, Florianópolis, Ano XXV, vol. 25, n. 51, p. 141-168, dez. 2005. 2007.

O inimigo no direito penal. Tradução de Sérgio Lamarão. 2. ed. Rio de Janeiro: Revan, 